Article

\title{
Hydrochemical and Quality Assessment of Groundwater Resources in Al-Madinah City, Western Saudi Arabia
}

\author{
Abdulaziz G. Alghamdi ${ }^{1, *(\mathbb{D}}$, Anwar A. Aly ${ }^{1,2} \mathbb{D}$, Sami Ali Aldhumri ${ }^{3}$ and \\ Fahad N. Al-Barakaha ${ }^{1}$ \\ 1 Department of Soil Sciences, College of Food and Agriculture Sciences, King Saud University, P.O. Box 2460, \\ Riyadh 11451, Saudi Arabia; aaaly@alexu.edu.eg (A.A.A.); barakah@ksu.edu.sa (F.N.A.-B.) \\ 2 Soil and Water Science Department, Alexandria University, Alexandria 21545, Egypt \\ 3 Department of Biology, Alkhormah University College, Taif University, Taif 21974, Saudi Arabia; \\ a.sami@tu.edu.sa \\ * Correspondence: agghamdi@ksu.edu.sa
}

Received: 1 March 2020; Accepted: 10 April 2020; Published: 13 April 2020

\begin{abstract}
Fifty-four groundwater samples were collected from Hamra Alasad in Al-Madinah City. The chemical and microbial characteristics of the samples were analyzed and compared with their respective standards. The results revealed that $90.7 \%$ of the samples showed higher amounts of $\mathrm{NO}_{3}$. However, $59.3 \%$ of the samples were found unfit for irrigation purposes due to a high salinity hazard. Most of the groundwater samples were highly saline, yet no sodicity hazards were anticipated as predicted by sodium adsorption ratio (SAR). Generally, the soluble cations and anions, dissolved salts, boron, and $\mathrm{NO}_{3}{ }^{-}$exceeded the maximum permissible limits for drinking water in most of the samples; however, $\mathrm{Pb}, \mathrm{Cd}, \mathrm{As}, \mathrm{Zn}, \mathrm{Cu}, \mathrm{Ni}, \mathrm{Co}, \mathrm{Fe}, \mathrm{Mn}$, and $\mathrm{Cr}$ were within the permissible limits. Furthermore, $42.6 \%, 24.1 \%, 18.5 \%, 14.8 \%, 1.9 \%$, and $37.0 \%$ of the samples were infected by a total coliforms group, fecal coliform, Escherichia coli, Staphylococcus sp., Salmonella sp., and Shigilla sp., respectively. The water quality index revealed that $3.7 \%$ of the samples were good for drinking (class II), and 9.3\% were very poor (class IV). The remaining samples were unfit for drinking (class V) due to high salinity and/or microbial contamination. Durov and Piper diagrams revealed that the majority of water samples were of the calcium sulfate-chloride type. Overall, $87 \%$ of water samples were inappropriate for drinking purposes, while $77.8 \%$ were unsuitable for irrigation.
\end{abstract}

Keywords: water resources; water quality index; irrigation; salinity hazard; mineral saturation index

\section{Introduction}

The Kingdom of Saudi Arabia (KSA), located in an arid environment, has limited renewable water resources [1]. There is a potential risk of water scarcity in the future due to a rapidly changing climate and anthropogenic activities [2]. The kingdom depends largely on the desalination of seawater and groundwater for different purposes such as drinking, irrigation, and industry [3]. Al-Madinah City is located in the western part of the KSA, and attracts a preponderance of religious tourists. It mainly depends on groundwater to meet its water requirements. Al-Madinah is one of the most significant cities in the KSA for historical and religion reasons. Various agricultural farms around Al-Madinah city conduct important agricultural activities including vegetables, dates, and alfalfa production. In Al-Madinah, there is a water stress due to the rapidly increasing population, extensive pumping out of groundwater resources, and prevalence of arid to semi-arid conditions [4]. This stress has undoubtedly led to the deterioration of the groundwater [1,5]. Hydrochemical characteristics including cations, anions, heavy metals, nitrates, chlorides, and organics of the groundwater to determine water 
quality indices should be used to help sustain the groundwater [6,7]. The chemical characteristics of groundwater, such as $\mathrm{pH}$, dissolved salts and gases, metals, and organics, are controlled by the exchange of cations within the geological aquifer, dissolution of minerals, and evaporation and redox reactions $[8,9]$. Spatiotemporal assessment and monitoring of the groundwater are essential for sustainability [10].

The water quality index (WQI) is an effective method to evaluate water quality and help policymakers. WQI integrates water quality parameters into a single number, which represents the quality of water [11-14]. The WQI has been successfully computed and applied by several researchers to investigate the water quality of water resources worldwide [11,14-19]. All WQI calculations depend on the integration of physiochemical parameters [10,19-21]. Backman et al. [22] used the WQI for evaluating the groundwater quality in Finland. Ketata-Rokbani et al. [23] presented the WQI with a GIS to evaluate the quality of the groundwater in Tunisia. Furthermore, Aly et al. [10,19] used the WQI to assess the water quality in the towns of Hafer Abatein and al-Kharj in the KSA. The groundwater in the city of Al-Madinah is mainly utilized for agricultural purposes, with some being used for industries [3]. Two aquifers are located in Al-Madinah, i.e., a sedimentary aquifer and a volcanic aquifer. It has been reported that the alluvium aquifer occupied an ancient basin, which was then covered by volcanic lava [24]. The abundance of water in this holy city, which is mainly used for human consumption, is a serious impediment for sustainable agricultural development. As there is a lack of a proper drainage system, salt accumulates in the soil, causing the deterioration of the groundwater quality in both the sedimentary and volcanic aquifers. Previous reports have concluded that the water quality in both aquifers is deteriorating due to salinization [3].

The aims of this investigation are to 1) assess the water quality of the Al-Madinah City groundwater for irrigation and drinking purposes by using the WQI, and 2) investigate the hydrochemical classification of the groundwater in Al-Madinah City.

\section{Materials and Methods}

\subsection{Study Area}

Al-Madinah City is situated in the KSA in the western part of Arabian Peninsula, known as the Arabian Shield province, around $400 \mathrm{~km}$ from Mecca City [25]. The holy city is located at $24^{\circ} 28^{\prime} \mathrm{N}$ and $39^{\circ} 36^{\prime}$ E. The city has a population of 995,619 inhabitants [26]; however, it exceeds 1.5 million in Hajj season. Its topography comprises of plains and hilly areas as well as valleys. Generally, the ground elevation in the plains ranges between $600 \mathrm{~m}$ and $620 \mathrm{~m}$ above mean sea level (AMSL). The mountainous areas are situated in the northern, southern, and western part of the city, with an elevation of $800 \mathrm{~m}$ to $1500 \mathrm{~m}$ AMSL. The slope of the area is from east to west until the slope reaches the Al-Aqiq valley. During last two decades, Al-Madinah has moved from being totally dependent on its groundwater to almost entirely dependent on desalinated water from the Yanbou Desalination Plant. The groundwater in the city is utilized in agriculture and some industries.

The climate of Al-Madinah City ranges from semi-arid to arid with a hot and dry environment. In the summer season, it is very hot and in the winter season it is moderately cold. The average temperature during summer ranges between $25-42^{\circ} \mathrm{C}$, whereas in winter it ranges between $10-24^{\circ} \mathrm{C}$ [24]. The temperature reaches its highest level during August, while its lowest level is during January. Most of the rainfall happens during November, December, and January, with occasional rainstorms taking place in April.

\subsection{Hydrology}

Saud et al. [3], stated that the total discharge of groundwater in Al-Madinah during 1968 was $2 \times 10^{5} \mathrm{~m}^{3}$, which exceeded the recharge value. This has resulted in a drawdown of $10 \mathrm{~m}$ over a period of 25 years. The total groundwater storage within the aquifer was estimated to be $5.7 \times$ $10^{9} \mathrm{~m}^{3}$. Saud et al. [3] pointed out that the sub-basaltic alluvium was more important, despite it 
having a low permeability. Moreover, the maximum amount of the groundwater stored within it was $7.5 \times 10^{8} \mathrm{~m}^{3}$. Al-Madinah's groundwater depression has formed due to over-pumping. A decline in the groundwater levels up to 0.1 to $0.15 \mathrm{~m} /$ month has been noticed, suggesting that the average annual input and output is $2.95 \times 10^{7} \mathrm{~m}^{3}$ and $4.05 \times 10^{7} \mathrm{~m}^{3}$, respectively, from the sub-basaltic alluvium aquifers. The Al-Madinah area was evaluated at having a shortage of $1.1 \times 10^{7} \mathrm{~m}^{3}$ [3]. The Water and Sewerage Directory of Al-Madinah reported the presence of two well fields in the southern parts of the city. Among them, the Quba well field comprises 31 wells, of which only two are currently functional with a production of $2000 \mathrm{~m}^{3} /$ day. These wells are approximately $110 \mathrm{~m}$ deep. All other wells were left un-operational, owing to their low production and/or a higher salinity levels. Lately, the well field in Abyar Almashi has been developed. Overall, the groundwater in Al-Madinah is characterized by high salinity, contamination in some sites, and continuous fluctuation of the water table in the aquifer due to withdrawals and low recharge.

\subsection{Chemical Analysis}

Fifty-four groundwater samples were gathered from Hamra Al-Asad in the Al-Madinah region (Figure 1). The depth of the wells ranged between 10-110 $\mathrm{m}$ (personal communications). All of the samples were stored in an icebox and transported to laboratories at the King Saud University in Riyadh for analysis. After testing the taste, the water samples were subjected to the following analyses: electric conductivity $(\mathrm{EC})$, water reaction $(\mathrm{pH})$, soluble ions (calcium $\left(\mathrm{Ca}^{2+}\right)$, magnesium $\left(\mathrm{Mg}^{2+}\right)$, sodium $\left(\mathrm{Na}^{+}\right)$, potassium $\left(\mathrm{K}^{+}\right)$, carbonate $\left(\mathrm{CO}_{3}{ }^{2-}\right)$, bicarbonate $\left(\mathrm{HCO}_{3}{ }^{-}\right)$, chloride $\left(\mathrm{Cl}^{-}\right)$, and sulfate $\left.\left(\mathrm{SO}_{4}{ }^{2-}\right)\right)$, nitrate $\left(\mathrm{NO}_{3}{ }^{-}\right)$, boron $(\mathrm{B})$, and heavy metals. The $\mathrm{EC}\left(\mathrm{dS} \cdot \mathrm{m}^{-1}\right)$ and $\mathrm{pH}$ were determined in the field using a portable EC/pH meter (Hanna, $\mathrm{HI}$ 9811-5). The ions $\mathrm{Mg}^{2+}$ and $\mathrm{Ca}^{2+}$ were determined using the titration method with ethylenediaminetetraacetic acid. In addition, $\mathrm{K}^{+}$and $\mathrm{Na}^{+}$were determined by a flame photometer (Corning 400) [27]. The ions $\mathrm{CO}_{3}{ }^{-2}$ and $\mathrm{HCO}_{3}{ }^{-}$were determined using acid titration; the $\mathrm{Cl}^{-}$ion was determined using silver nitrate titration [27]. Furthermore, $\mathrm{SO}_{4}{ }^{2-}$ was estimated using a turbidity procedure [28], while $\mathrm{NO}_{3}{ }^{-}$and $\mathrm{B}$ were established using methods utilizing phenoldisulfonic acid and azomethine- $\mathrm{H}$, respectively $[29,30]$.

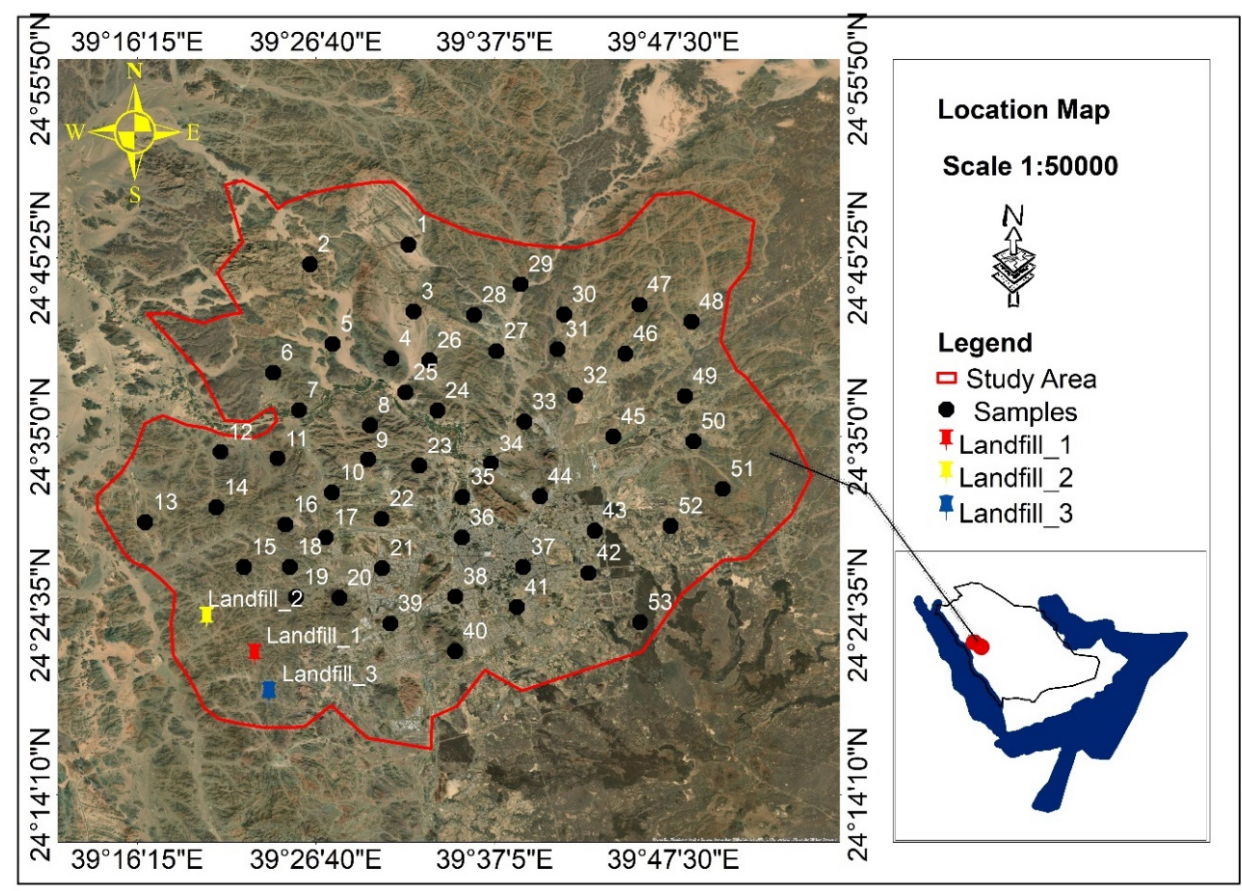

Figure 1. Geological map of the study area and sampling points of Al-Madinah City, Western Saudi Arabia. 
Water samples for heavy metal analyses were filtered and acidified using $\mathrm{HNO}_{3}$ to a $\mathrm{pH}<2$. Furthermore, the analyses of the heavy metals were carried out using an ICP PerkinElmer Model 4300DV [29,31].

\subsection{Microbial Analysis}

The total colony count was determined by nutrient agar methods; however, the coliforms (as one group) and E. coli were determined by the Colilert or defined substrate methods, as described by Edberg et al. [32], Fricker et al. [33], Eckner [34], and Maheux et al. [35].

\subsection{WQI Computing}

The chemistry of the groundwater was explored by computing the WQI. It has been established that the WQI is a vital parameter for measuring the groundwater quality. The WQI can be calculated by assigning a relative weight (wi) to each parameter based on their importance in the overall water quality. Briefly, the calculations of the WQI comprised three steps as follows $[10,11,14-17,36]$.

\subsubsection{Assigning Weight}

The 13 parameters were given a weight (wi) according to their significance in determining drinking water quality (Table 1 ). The wi was calculated by using a weighted arithmetic index method as reported by Ramakrishnaiah et al. [37]. The weights ranged between 1 and 5 , with 5 being the utmost important parameter and 1 being the least important parameter (Table 1) [37].

Table 1. Relative weight for parameters for the groundwater collected from Al-Madinah City, Western Saudi Arabia.

\begin{tabular}{cccc}
\hline Chemical Parameters & Weights (wi) & Relative Weight (wi) & WHO Standard \\
\hline pH & 3 & 0.073 & 8.5 \\
TDS & 4 & 0.098 & 600 \\
Calcium & 2 & 0.049 & 75 \\
Magnesium & 2 & 0.049 & 50 \\
Sodium & 2 & 0.049 & 200 \\
Potassium & 2 & 0.049 & 12 \\
Bicarbonate & 2 & 0.049 & 120 \\
Chloride & 3 & 0.073 & 250 \\
Sulfate & 3 & 0.073 & 250 \\
Nitrate & 5 & 0.122 & 10 \\
Boron & 3 & 0.073 & 0.5 \\
As & 5 & 0.122 & 0.01 \\
Cd & 5 & 0.122 & 0.003 \\
\hline Total coliform & Unsuitable & & \\
\hline Total & 41 & 1.000 & \\
\hline
\end{tabular}

\subsubsection{Relative Weight $\left(W_{i}\right)$}

Wi was calculated as follows:

$$
W_{i}=\frac{w_{i}}{\sum_{i=1}^{n} w_{i}}
$$

where $W_{i}$ is the weight of the parameter and $n$ is the total number of parameters (Table 1 ).

\subsubsection{Quality Rating Scale $\left(q_{i}\right)$}

The $q_{i}$ was calculated by dividing the water sample concentration to a respective standard, as follows:

$$
q_{i}=\frac{C_{i}}{S_{i}} \times 100
$$


where $C_{i}$ is the concentration $\left(\mathrm{mg} \mathrm{L}^{-1}\right)$ and $S i$ is the permissible limit value as given by the WHO standard [38]. Lastly, the sub-index of $i$ th parameter (SIi) of each chemical parameter was calculated as follows:

$$
S I_{i}=W_{i} \times q_{i}
$$

Then, the WQI was calculated by taking a sum of all calculated sub-indices as follows:

$$
W Q I=\sum_{i=1}^{n} S l_{i}
$$

The values of the $W Q I$ were classified into five classes (Table 2).

Table 2. Water quality classification ranges and types based on the calculated water quality indices (WQI) values.

\begin{tabular}{ccc}
\hline WQI Range & Class & Type of Water \\
\hline$<50$ & I & Excellent water \\
$50-100.1$ & II & Good water \\
$100-200.1$ & III & Poor water \\
$200-300.1$ & IV & Very poor water \\
$>300$ & V & Water unsuitable for drinking \\
\hline
\end{tabular}

\subsection{Hydrochemical Characteristics}

To investigate the hydrochemical characteristics of the collected water samples, the Piper, Schoeller, and Durov diagrams were constructed by using Geochemistry Software AquaChem 2014.2 to identify the water type $[39,40]$. In addition, hazards due to salinity, sodium adsorption ratio (SAR), total hardness $(\mathrm{TH})$, and Kelly's ratio (KR) were computed.

\subsection{Geochemical Modeling: The Saturation Index (SI)}

The SI of a mineral was calculated using the PHREEQC model [41] (Equation (5)):

$$
\mathrm{SI}=\log \mathrm{IAP} / k_{t}
$$

where IAP is the Ion Activity Product of the mineral and $k_{t}$ is the solubility at chemical equilibrium [42].

\subsection{Statistical Analyses}

The statistical analyses carried out included the determination of maximum, minimum, average, standard deviation, variance, standard error, median, and skewness. These analyses were conducted using Excel [10].

\section{Results and Discussion}

\subsection{Groundwater Evaluation for Drinking}

A total of $42.6 \%, 24.1 \%, 18.5 \%, 14.8 \%, 1.9 \%$, and $37.0 \%$ of waters were infected by total coliforms, fecal coliforms, E. coli, Staphylococcus sp., Salmonella sp., and Shigilla sp., respectively (Table 3). This finding is in agreement with the finding of Al-Makishah [43]. 
Table 3. Microbial analyses of the groundwater samples collected from Al-Madinah City, Western Saudi Arabia.

\begin{tabular}{|c|c|c|c|c|c|c|}
\hline \multirow{2}{*}{ Sample No } & Total Coliform & Fecal Coliform & E. coli & Staphylococcus sp. & Salmonella sp. & Shigilla sp. \\
\hline & X10 & & & $10^{6}$ & \multicolumn{2}{|c|}{$\mathrm{cfu} / \mathrm{mL}$} \\
\hline 1 & 10 & 4 & 2 & Nil & 1 & $16 \times 10^{5}$ \\
\hline 2 & 20 & 13 & 12 & Nil & Nil & $18 \times 10^{5}$ \\
\hline 3 & 2 & Nil & Nil & Nil & Nil & $48 \times 10^{9}$ \\
\hline 4 & 32 & 8 & Nil & 1 & Nil & Nil \\
\hline 5 & 50 & 6 & 2 & 1 & Nil & Nil \\
\hline $6-9$ & Nil & Nil & Nil & Nil & Nil & Nil \\
\hline 10 & 10 & Nil & Nil & Nil & Nil & $32 \times 10^{5}$ \\
\hline $11-12$ & Nil & Nil & Nil & Nil & Nil & Nil \\
\hline 13 & 51 & Nil & Nil & Nil & Nil & Nil \\
\hline 14 & Nil & Nil & Nil & Nil & Nil & Nil \\
\hline 15 & 8 & 4 & 1 & Nil & Nil & $7 \times 10^{9}$ \\
\hline $16-18$ & Nil & Nil & Nil & Nil & Nil & Nil \\
\hline 19 & 19 & 11 & 3 & Nil & Nil & $64 \times 10^{5}$ \\
\hline $20-24$ & Nil & Nil & Nil & Nil & Nil & Nil \\
\hline 25 & 13 & Nil & Nil & Nil & Nil & $21 \times 10^{9}$ \\
\hline 26 & 21 & 9 & 2 & 66 & Nil & $40 \times 10^{9}$ \\
\hline $27-30$ & Nil & Nil & Nil & Nil & Nil & Nil \\
\hline 31 & 40 & 32 & 30 & 20 & Nil & $32 \times 10^{9}$ \\
\hline 32 & 13 & 7 & Nil & 114 & Nil & $48 \times 10^{9}$ \\
\hline 33 & 12 & 9 & 8 & 113 & Nil & $13 \times 10^{8}$ \\
\hline 34 & 41 & Nil & Nil & Nil & Nil & $20 \times 10^{9}$ \\
\hline 35 & 3 & Nil & Nil & Nil & Nil & $79 \times 10^{9}$ \\
\hline 36 & 88 & 52 & 4 & Nil & Nil & $57 \times 10^{9}$ \\
\hline 37 & 37 & Nil & Nil & Nil & Nil & $112 \times 10^{9}$ \\
\hline 38 & Nil & Nil & Nil & Nil & Nil & Nil \\
\hline 39 & 39 & Nil & Nil & 3 & Nil & $68 \times 10^{9}$ \\
\hline 40 & 40 & Nil & Nil & 104 & Nil & $28 \times 10^{9}$ \\
\hline 41 & $\mathrm{Nil}$ & Nil & Nil & Nil & Nil & Nil \\
\hline $42-43$ & 42 & Nil & Nil & Nil & Nil & $44 \times 10^{9}$ \\
\hline 44 & Nil & Nil & $\mathrm{Nil}$ & Nil & Nil & Nil \\
\hline 45 & 450 & 3 & Nil & Nil & Nil & $24 \times 10^{9}$ \\
\hline $46-50$ & $\mathrm{Nil}$ & Nil & Nil & Nil & Nil & Nil \\
\hline 51 & 510 & 16 & 14 & Nil & Nil & $88 \times 10^{9}$ \\
\hline $52-54$ & Nil & Nil & Nil & Nil & Nil & Nil \\
\hline
\end{tabular}

The results showed that some of the groundwater samples had a noticeably bitter taste due to the predominance of $\mathrm{Ca}^{2+}$. Nonetheless, according to the WHO, calcium from the calcium-rich water is well absorbed by the human body and retained, just as the calcium from milk is retained [44]. The results revealed that the $\mathrm{pH}$ values of the collected groundwater samples ranged from 6.5 to 8.4 with an average of 7.1, suggesting safe limits. However, based on EC values, $77.8 \%$ of the groundwater samples were categorized as having a high salinity hazard, mainly due to highly dissolved soluble ions (Table 4). Thus, most of the groundwater samples were not suitable for drinking purposes. The concentrations of $\mathrm{NO}_{3}$ in the collected groundwater samples ranged from $1.8 \mathrm{mg} \mathrm{L}^{-1}$ to $304.2 \mathrm{mg} \mathrm{L}^{-1}$ with an average of $117.9 \mathrm{mg} \mathrm{L}^{-1}$ (Table 5). The results showed that $50 \%$ of the water samples had $\mathrm{NO}_{3}$ concentrations more than $100 \mathrm{mg} \mathrm{L}^{-1}$, which were above the permissible limit $\left(50 \mathrm{mg} \mathrm{NO}_{3} \mathrm{~L}^{-1}\right.$ ) for public drinking water supplies [38]. 
Table 4. Descriptive statistics of the studied groundwater chemical composition.

\begin{tabular}{|c|c|c|c|c|c|c|c|c|c|c|}
\hline \multirow{2}{*}{ No } & \multirow{2}{*}{$\mathrm{pH}$} & \multirow{2}{*}{$\begin{array}{c}\text { EC } \\
\left(\mathrm{dS} \cdot \mathrm{m}^{-1}\right)\end{array}$} & \multicolumn{4}{|c|}{ Cations (meq $\mathrm{L}^{-1}$ ) } & \multicolumn{4}{|c|}{ Anions (meq $\mathrm{L}^{-1}$ ) } \\
\hline & & & $\mathrm{Ca}^{2+}$ & $\mathrm{Mg}^{2+}$ & $\mathrm{Na}^{+}$ & $\mathrm{K}^{+}$ & $\mathrm{CO}_{3}{ }^{2-}$ & $\mathrm{HCO}_{3}{ }^{-}$ & $\mathrm{Cl}^{-}$ & $\mathrm{SO}_{4}{ }^{2-}$ \\
\hline Maximum & 8.4 & 8.3 & 38.2 & 19.5 & 39.8 & 0.7 & 2.8 & 8.8 & 51.3 & 30.1 \\
\hline Minimum & 6.5 & 0.5 & 1.0 & 0.6 & 0.7 & 0.0 & 0.0 & 0.1 & 0.7 & 2.1 \\
\hline Mean & 7.1 & 4.4 & 16.1 & 7.3 & 18.2 & 0.1 & 0.1 & 3.8 & 23.2 & 15.2 \\
\hline $\begin{array}{c}\text { St. } \\
\text { deviation }\end{array}$ & 0.4 & 1.7 & 9.9 & 3.6 & 7.5 & 0.1 & 0.4 & 1.9 & 10.4 & 7.6 \\
\hline Median & 7.1 & 4.8 & 14.5 & 6.8 & 17.1 & 0.1 & 0.0 & 3.8 & 22.1 & 15.0 \\
\hline Skew & 1.1 & -0.3 & 0.5 & 0.7 & 0.4 & 2.9 & 7.3 & 0.7 & 0.1 & 0.1 \\
\hline
\end{tabular}

EC is the electrical conductivity, $\mathrm{Ca}^{2+}$ is calcium ion, $\mathrm{Mg}^{2+}$ is magnesium ion, $\mathrm{Na}^{+}$is sodium ion, $\mathrm{K}^{+}$is potassium ion, $\mathrm{CO}_{3}{ }^{2-}$ is carbonate, $\mathrm{HCO}_{3}{ }^{-}$is bicarbonate, $\mathrm{Cl}^{-}$is chloride, and $\mathrm{SO}_{4}{ }^{2-}$ is sulfate.

Table 5. Descriptive statistics of the water quality indicators (WQI) of the studied groundwater samples collected from Al-Madinah, Western Saudi Arabia.

\begin{tabular}{ccccccccc}
\hline \multirow{2}{*}{ No. } & $\mathbf{N O}_{3}{ }^{-}$ & $\mathbf{B}$ & \multirow{2}{*}{$\mathbf{S A R}$} & $\mathbf{M H}$ & $\mathbf{R S C}$ & $\mathbf{K R}$ & $\mathbf{T H}\left(\mathbf{C a C O}_{\mathbf{3}} \mathbf{~ m g} / \mathbf{L}\right)$ & Indication \\
\cline { 2 - 6 } $\mathbf{m g ~ L}^{-\mathbf{1}}$ & & & & & & & \\
\hline Maximum & 304.2 & 4.7 & 10.2 & 0.7 & -0.2 & 1.8 & 2447.0 & Very hard water \\
Minimum & 1.8 & 0.0 & 0.6 & 0.1 & -46.9 & 0.3 & 116.0 & Hard water \\
Mean & 117.9 & 1.5 & 5.5 & 0.4 & -19.5 & 0.9 & 1162.3 & Very hard water \\
St. deviation & 67.3 & 0.8 & 2.0 & 0.2 & 12.3 & 0.4 & 581.2 & \\
Median & 101.5 & 1.4 & 5.2 & 0.3 & -18.2 & 0.9 & 1133.0 & \\
Skew & 0.5 & 1.3 & 0.3 & 0.6 & -0.3 & 0.2 & 0.2 & \\
\hline
\end{tabular}

$\mathrm{NO}_{3}{ }^{-}$is nitrate ion, $\mathrm{B}$ is boron, SAR is the sodium adsorption ratio, $\mathrm{MH}$ is the magnesium hazard, RSC is the residual sodium carbonate, $\mathrm{KR}$ is Kelly's ratio, and TH is total hardness.

Based on the calculated values of the water quality index (WQI), about $3.7 \%$ of the water samples were suitable for drinking purpose (class II), and 9.3\% were very poor water (class IV). The rest of the samples were found to be unfit for drinking purposes (class V) due to high salinity and/or microbial contamination (Figure 2). Most of the groundwater in Al-Madinah is used for agricultural purposes [45]. These results are in agreement with the study of Fallatah [2] and Sharaf [4].

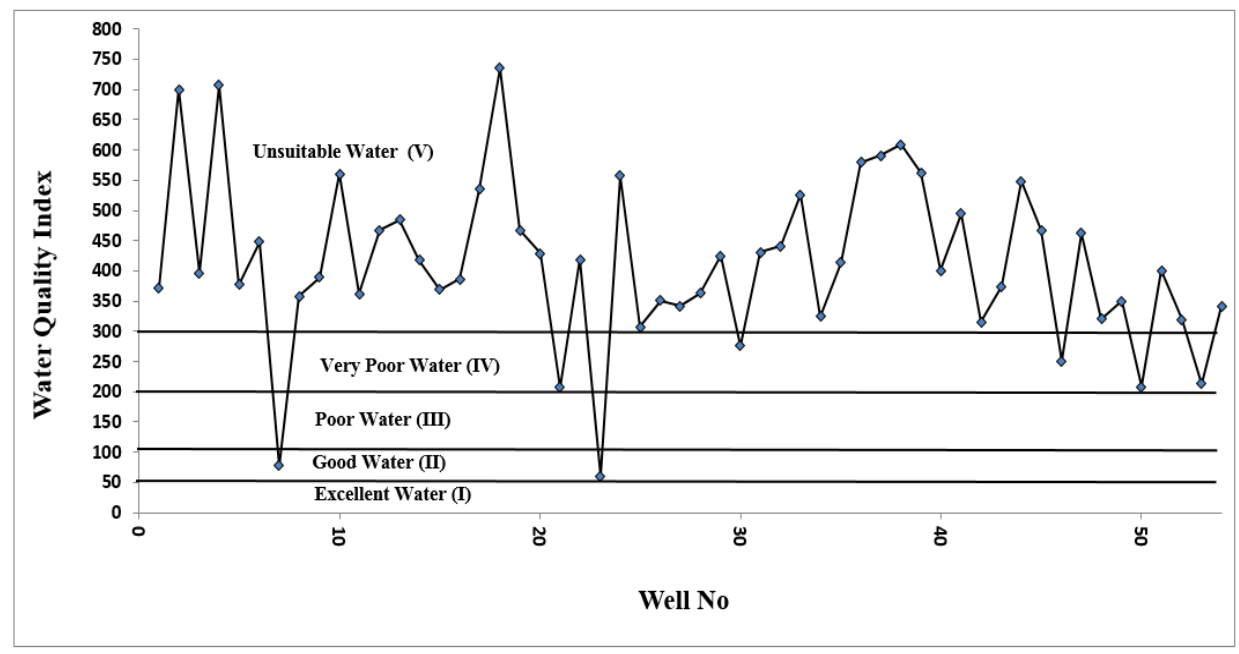

Figure 2. The calculated values of the water quality index (WQI) of the groundwater samples collected from Al-Madinah City, Western Saudi Arabia.

\subsection{Groundwater Evaluation for Irrigation}

The chemical analyses of the Al-Madinah groundwater samples were analyzed statistically (Tables 4 and 5). 
Figure 3 shows that the order of cation concentrations is as: $\mathrm{Ca}^{2+}>\mathrm{Na}^{+}+\mathrm{K}^{+}>\mathrm{Mg}^{2+}$; whereas, the order of anions concentrations is as: $\mathrm{Cl}^{-}>\mathrm{SO}_{4}{ }^{2-}>\mathrm{HCO}_{3}{ }^{-}$. The results revealed that the collected groundwater samples contained a pH of 6.5-8.4, with an average of 7.1 (Table 4). The acceptable limit of $\mathrm{pH}$ for irrigation water is between 6.5 and 8.4 [46]. Consequently, all water samples were within an acceptable limit due to $\mathrm{pH}$ values $[45,47]$. The EC ranged between $0.5 \mathrm{dS} \mathrm{m}^{-1}$ to $8.3 \mathrm{dS} \mathrm{m}^{-1}$, with an average value of $4.4 \mathrm{dS} \mathrm{m}^{-1}$ (Table 4). According to the classification by Ayers and Westcot [46], 3.7\% of the water samples had no degree of restriction for use in irrigation. However, $18.5 \%$ of the water samples had slight to moderate salinity. Finally, $77.8 \%$ of the groundwater samples were categorized as having a high salinity hazard. One of the significant methods for defining the hazard of sodium is the sodium adsorption ratio (SAR) [48], which was calculated as follows:

$$
\mathrm{SAR}=\frac{\mathrm{Na}}{\sqrt{\frac{\mathrm{Ca}+\mathrm{Mg}}{2}}}
$$

where meq $\mathrm{L}^{-1}$ is the unit for expressing cations $(\mathrm{Na}, \mathrm{Ca}$, and $\mathrm{Mg})$.
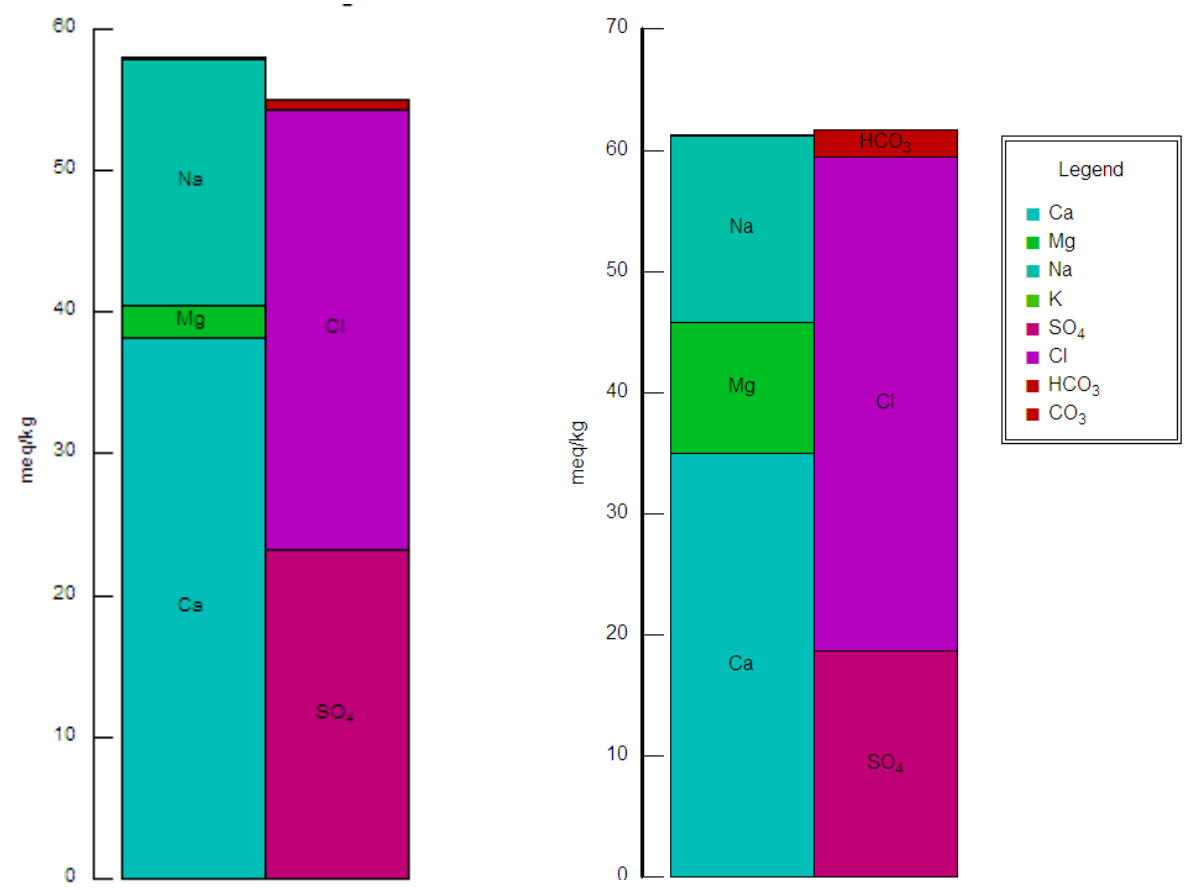

Figure 3. Ion balance diagram of samples 1 and 24 depicting the dominance of calcium in some areas of Al-Madinah City, Western Saudi Arabia.

The values of the SAR ranged between 0.6 and 10.2, with a mean of 5.5 (Table 2). Moreover, $96.3 \%$ of the SAR values were $<10$. Consequently, the water could be classified as excellent for irrigation with respect to the sodium hazard [49]. Kelly's ratio (KR) [50] was calculated as:

$$
\mathrm{KR}=\frac{\mathrm{Na}}{\mathrm{Ca}+\mathrm{Mg}}
$$

where meq $\mathrm{L}^{-1}$ is the unit for expressing cations $(\mathrm{Na}, \mathrm{Ca}$, and $\mathrm{Mg})$ and $\mathrm{KR}>1$ indicates a high hazard from sodium.

Thus, $61 \%$ of the water samples had a $\mathrm{KR}<1$, indicating that they did not have any sodium hazards; instead, $39 \%$ of the water samples had a KR $>1$, which represented a high sodium hazard if the waters were used for irrigation (Table 2). 
The residual sodium carbonate (RSC) was calculated from Equation (8) as follows:

$$
\mathrm{RSC}=\left(\mathrm{CO}_{3}{ }^{-}+\mathrm{HCO}_{3}{ }^{-}\right)-\left(\mathrm{Ca}^{2+}+\mathrm{Mg}^{2+}\right)
$$

where the cations and anions in Equation (8) are expressed in meq $\mathrm{L}^{-1}$.

A (-) value for the RSC showed that sodium was not likely to be a problem due to adequate amounts of magnesium and calcium, which were in surplus of magnesium and calcium precipitated in the form of carbonates. All samples had a negative RSC, indicating that there was no sodium hazard (Table 2) [51].

Magnesium hazard (MH) was calculated as follows [52]:

$$
\mathrm{MH}=\frac{\mathrm{Mg}}{\mathrm{Ca}+\mathrm{Mg}} \times 100
$$

where the calcium and magnesium were in units of meq $\mathrm{L}^{-1}$.

If $\mathrm{MH}<50$, the water is safe for irrigation [52]. In this study, all of the samples had an $\mathrm{MH}<50$; consequently, they could be considered as suitable for irrigation with respect to $\mathrm{MH}$ (Table 2). The $\mathrm{NO}_{3}{ }^{-}$ concentrations in the groundwater samples ranged between 1.8 and $304.2 \mathrm{mg} \mathrm{L}^{-1}$, with a mean of $117.9 \mathrm{mg} \mathrm{L}^{-1}$ (Table 2); $50 \%$ of the water samples had $\mathrm{NO}_{3}{ }^{-}$concentrations greater than $100 \mathrm{mg} \mathrm{L}^{-1}$, probably because of the usage of chemical fertilizers in agricultural production [53]. Of the samples, $18.5 \%$ had boron (B) concentration within the permissible limit. However, $75.9 \%$ of the samples had a slight to moderate degree of restriction for use in irrigation. The remaining samples had a severe $B$ hazard because their B concentration was more than $3 \mathrm{mg} / \mathrm{L}$ (Table 2) [1,45].

\subsection{Hydrochemical Aspects}

The Piper and Schoeller [45] diagrams (Figure 4) revealed that the main water type identified in the Al-Madinah groundwater was calcium-magnesium/sulfate-chloride, and this represented $74 \%$ of collected samples. However, $26 \%$ of samples showed a water type of sodium-potassium/sulfate-chloride. These water types indicated that the geological composition in the area was mainly gypsum, anhydrite, and halite.

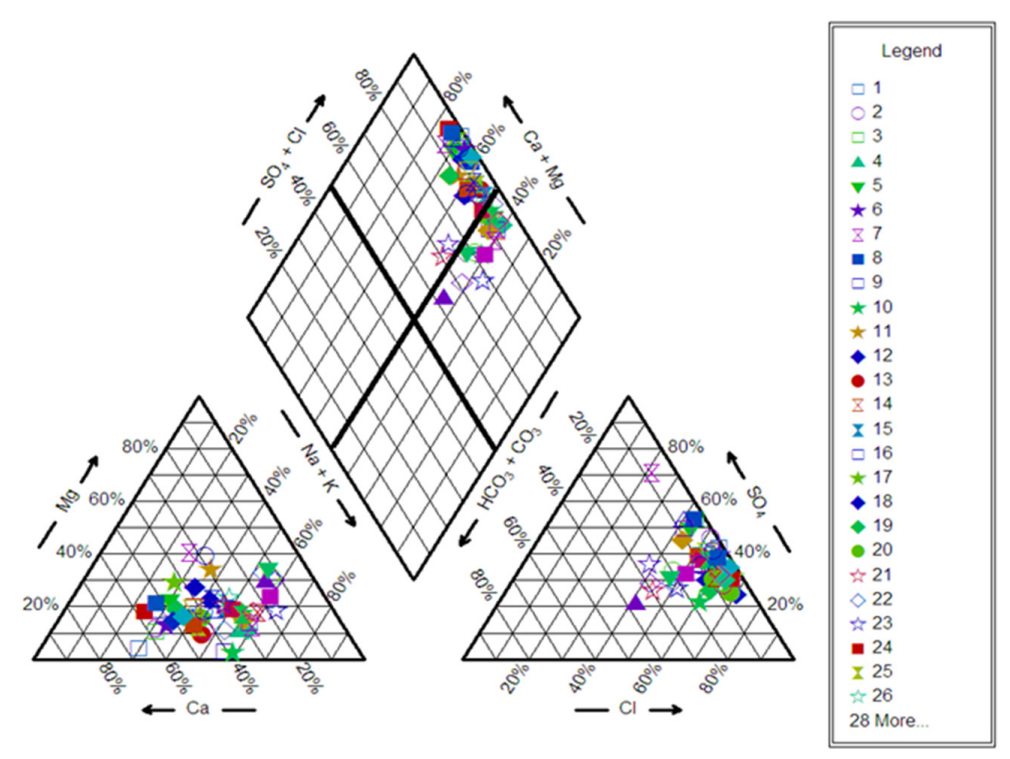

Figure 4. Piper diagram for the groundwater samples collected from Al-Madinah City, Western Saudi Arabia. 
Durov's diagram (Figure 5) showed that the groundwater samples fell in fields 4 and 5 . The fitting of samples in field 4 showed the occurrence of $\mathrm{Ca}^{2+}$ and $\mathrm{SO}_{4}{ }^{2-}$ as the dominant ions in the water and they reflected the gypsum-bearing sedimentary aquifer; the water was affected by oxidation of pyrite and sulfide minerals. Field 5 showed that mixing occurred between two or more different facies $[9,36]$.

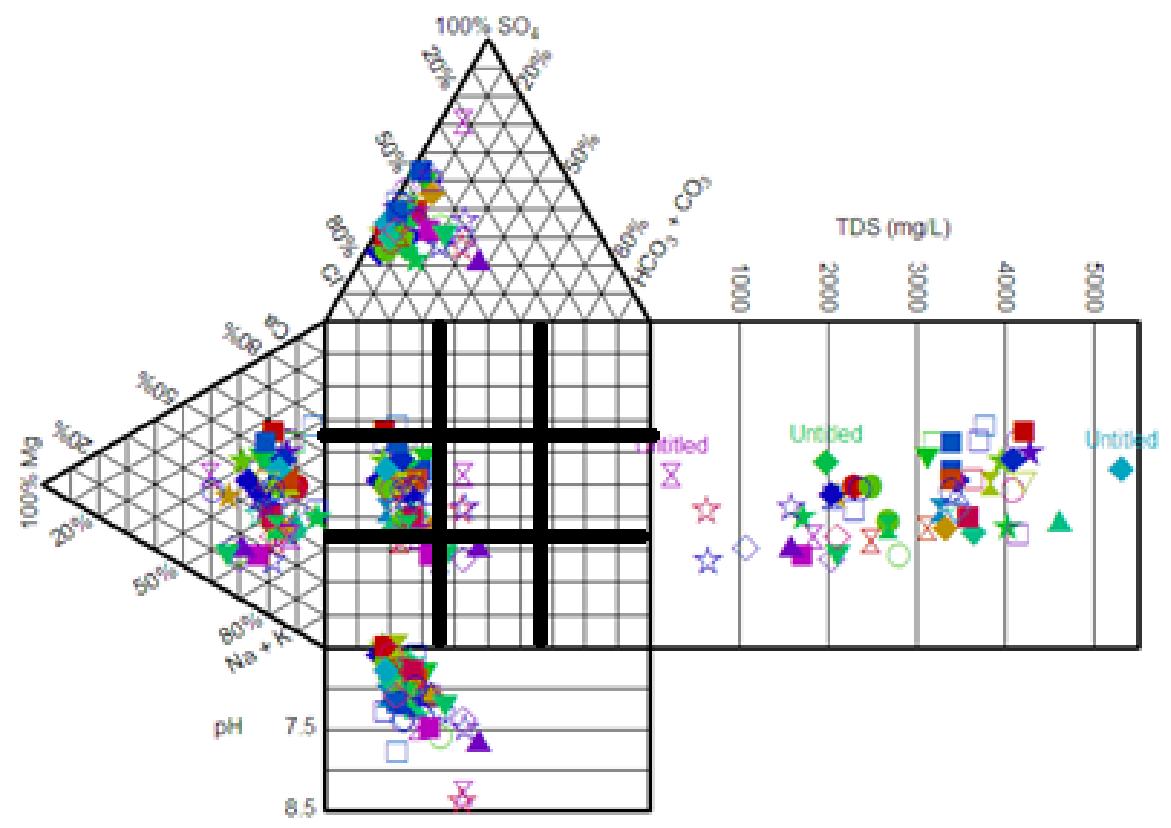

Figure 5. Durov diagram for the groundwater samples collected from Al-Madinah City, Western Saudi Arabia.

\subsection{Geochemical Modeling}

Groundwater is considered to be saturated with minerals if $-1<\mathrm{SI}<+1$; moreover, if $\mathrm{SI}$ is less than -1 , the groundwater is assumed to be undersaturated and if SI is above +1 , it assumed to be oversaturated [54].

Mineral saturation indices (SI) of the groundwater samples were calculated using the model of PHREEQC [19,55] (Figure 6). The results showed that most sites contained the following minerals in their aquifers: anhydrite $\left(\mathrm{CaSO}_{4}\right)$, goethite $(\mathrm{FeOOH})$, gypsum $\left(\mathrm{CaSO}_{4}: 2 \mathrm{H}_{2} \mathrm{O}\right)$, halite $(\mathrm{NaCl})$, hematite $\left(\mathrm{Fe}_{2} \mathrm{O}_{3}\right)$, jarosite- $\mathrm{K}\left(\mathrm{KFe}_{3}\left(\mathrm{SO}_{4}\right)_{2}(\mathrm{OH})_{6}\right)$, and melanterite $\left(\mathrm{FeSO}_{4}: 7 \mathrm{H}_{2} \mathrm{O}\right)$. However, only samples 1, 2, 3, 7, 8, and 20 contained ausmannite $\left(\mathrm{Mn}_{3} \mathrm{O}_{4}\right)$, manganite $(\mathrm{MnOOH})$, pyrochroite $\left(\mathrm{Mn}(\mathrm{OH})_{2}\right)$, and pyrolusite $\left(\mathrm{MnO}_{2}\right)$. The water samples were found to be undersaturated with halite, hausmannite, jarosite-K, manganite, melanterite, pyrochroite, and pyrolusite. In addition, $22.2 \%$ and $27.8 \%$ of the water samples were undersaturated with sulfate minerals of gypsum and anhydrite, respectively; suggesting more soluble $\mathrm{Ca}^{2+}$ and $\mathrm{SO}_{4}{ }^{2-}$ dissolved in the groundwater samples. The higher contents of $\mathrm{SO}_{4}{ }^{2-}$ could be due to the oxidative dissolution of pyrite [56]. However, the remaining samples were saturated with both minerals. Furthermore, the water samples were found to be oversaturated with respect to goethite and hematite. Unsaturated minerals have a tendency to dissolve in water samples [19,57]. Thus, there is an option for an increase in the concentrations of soluble ions dissolved in the groundwater. This result is in agreement with the results of Al-Barakah et al [58] and Fallatah [2] on their study of Arabian Shield groundwater. 

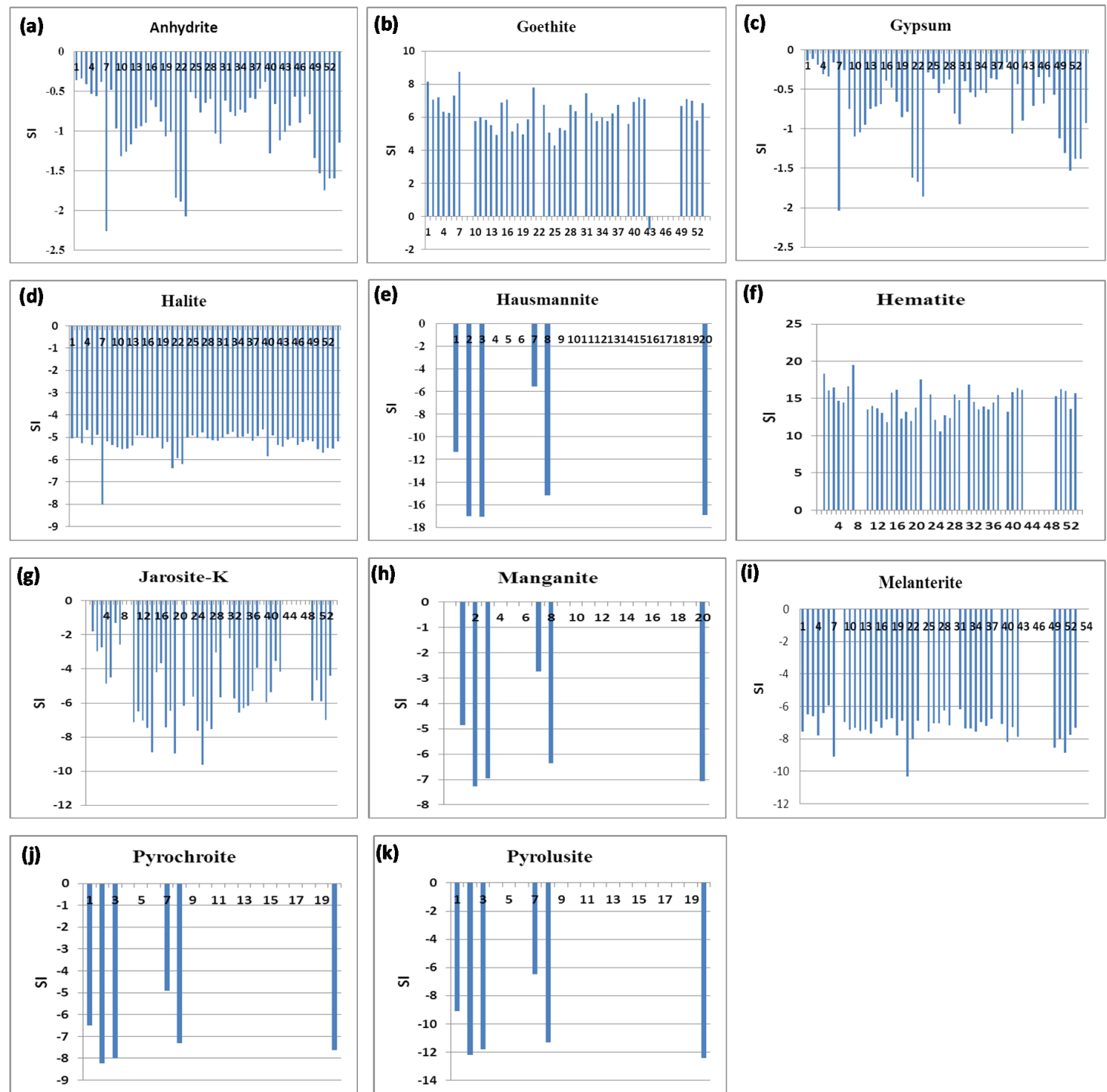

Figure 6. Mineral saturation indices of the groundwater samples collected from Al-Madinah City, Western Saudi Arabia (a): anhydrite, (b): geothite, (c): gypsum, (d): halite, (e): hausmannite, (f): hematite, $(\mathbf{g})$ : jarosite-K, (h): manganite, $(\mathbf{i})$ : melanterite, $(\mathbf{j})$ : pyrochroite, and $(\mathbf{k})$ : pyrolusite.

\section{Conclusions}

A total of 54 groundwater samples were collected from Al-Madinah City, Western Saudi Arabia and their hydrochemical characteristics as well as quality were investigated. Various calculated water quality indices (WQI) showed that $87 \%$ of the samples were unsuitable for drinking purposes owing to their higher salinity levels and/or microbial contamination. Based on the obtained results of soluble salts, electrical conductivity (EC), and SAR, it was observed that only $3.7 \%$ of the water samples were fit for use in irrigation. Likewise, $18.5 \%$ of the water samples had slight to moderate salinity, while $77.8 \%$ of the water samples exhibited a higher salinity hazard. A total of $96.3 \%$ of the SAR values were $<10$, indicating that the water was excellent for irrigation. On the other hand, $61 \%$ of the samples had a $K R<1$, suggesting that the waters did not have any sodium hazard, whereas $39 \%$ of the samples had a KR $>1$, indicating a higher sodium hazard. Contrarily, all of the samples exhibited a magnesium hazard value of more than 50, suggesting their suitability for irrigation. Based on $\mathrm{NO}_{3}{ }^{-}$, and boron (B) concentrations in the water samples, $75.9 \%$ of the samples had a slight to moderate degree of restriction for use in irrigation. The remaining samples were considered to be severely hazardous due to higher B contents. The Piper and Schoeller diagrams revealed that the main water types identified in the groundwater of 
Al-Madinah City were calcium-magnesium/sulfate-chloride and sodium-potassium/sulfate-chloride, whereas the Durov's diagram showed that the groundwater samples fell in fields 4 and 5, suggesting the presence of $\mathrm{Ca}^{2+}$ and $\mathrm{SO}_{4}{ }^{-2}$ in the dominant water type. The results of the mineral saturation indices (SI) exhibited that most of the sampling sites were undersaturated with halite, hausmannite, jarosite-K, manganite, melanterite, pyrochroite, and pyrolusite. Therefore, it was concluded that $77.8 \%$ of water samples collected from Al-Madinah City were unsuitable for irrigation, whereas $87 \%$ were unsuitable for drinking purposes.

Author Contributions: Conceptualization, A.G.A. and F.N.A.-B.; methodology, A.A.A.; software, A.A.A.; validation, S.A.A. and A.G.A.; formal analysis, A.A.A.; investigation, A.A.A. and F.N.A.-B.; resources, A.G.A.; data curation, S.A.A.; writing and editing, A.G.A., A.A.A., S.A.A., and F.N.A.-B. All authors have read and agree to the published version of the manuscript.

Funding: This research was funded by [Deanship of Scientific Research at King Saud University] grant number [RG- 1440-089].

Acknowledgments: The authors extend their appreciation to the Deanship of Scientific Research at King Saud University for funding this work.

Conflicts of Interest: The authors declare no conflict of interest.

\section{References}

1. Al-Omran, A.M.; Aly, A.A.; Al-Wabel, M.I.; Sallam, A.S.; Al-Shayaa, M.S. Hydrochemical Characterization of Groundwater under Agricultural Land in Arid Environment: A Case Study of Al-Kharj, Saudi Arabia. Arab. J. Geosci. 2016, 9, 68-85. [CrossRef]

2. Fallatah, O.A. Groundwater Quality Patterns and Spatiotemporal Change in Depletion in the Regions of the Arabian Shield and Arabian Shelf. Arab. J. Sci. Eng. 2020, 45, 341-350. [CrossRef]

3. Saud, A.G.; Abdullah, S.A. Water Resources and Reuse in Al-Madinah. In Proceedings of the International Conference on Water Conservation in Arid Regions (ICWCAR'09), Water Research Center-King Abdulaziz University, Jeddah, Saudi Arabia, 12-14 October 2009; pp. 12-14.

4. Sharaf, M.A.M. Major elements hydrochemistry and groundwater quality of Wadi Fatimah, West Central Arabian Shield, Saudi Arabia. Arab. J. Geosci. 2013, 6, 2633-2653. [CrossRef]

5. Al-Omran, A.M.; Aly, A.A.; Sallam, A.S. A Holistic Ecosystem Approach for the Sustainable Development of Fragile Agro-Ecosystems: A Case Study of the Al-Kharj Ecosystem, Saudi Arabia. National Science, Technology and Innovation Plan, Kingdom of Saudi Arabia. Available online: http://rp.ksu.edu.sa/sites/rp. ksu.edu.sa/files/res-files/Detailed\%20Report\%20(12\%20month\%20Kharj)5.pdf (accessed on 20 May 2019).

6. Ledesma-Ruiz, R.; Pastén-Zapata, E.; Parra, R.; Harter, T.; Mahlknecht, J. Investigation of the geochemical evolution of groundwater under agricultural land: A case study in northeastern Mexico. J. Hydrol. 2015, 521, 410-423. [CrossRef]

7. El-Sayed, M.H.; Abo El-Fadl, M.M.; Shawky, H.A. Impact of hydrochemical Processes on Groundwater Quality, Wadi Feiran, South Sinai, Egypt. Aust. J. Basic App. Sci. 2012, 6, 638-654.

8. Matthess, G. The Properties of Groundwater; Wiley: New York, NY, USA, 1982; p. 498.

9. Kumar, M.; Ramanathan, A.L.; Rao, M.S.; Kumar, B. Identification and evaluation of hydrogeochemical processes in the groundwater environment of Delhi, India. J. Environ. Geol. 2006, 50, 1025-1039. [CrossRef]

10. Aly, A.A.; Gaber, H.M.; Kishk, F.M.; Al-Omran, A.M. Long-term detection and hydrochemistry of groundwater resources in Siwa Oasis, Egypt. J. Saudi Soc. Agric. Sci. 2016, 15, 67-74. [CrossRef]

11. Lateef, K.H. Evaluation of Groundwater Quality for Drinking Purpose for Tikrit and Samarra Cities using Water Quality Index. Eur. J. Sci. Res. 2011, 58, 472-481.

12. Stambuck-Giljanovic, N. Water quality evaluation by index in Dalmatia. Water Res. 1999, 33, 3426-3440. [CrossRef]

13. Stigter, T.Y.; Ribeiro, L.; Carvalho Dill, A.M. Application of a groundwater quality index as an assessment and communication tool in agro-environmental policies-Two Portuguese case studies. J. Hydrol. 2006, 327, 578-591. [CrossRef]

14. Saeedi, M.; Abessi, O.; Sharifi, F.; Meraji, H. Development of groundwater quality index. Environ. Monit. Assess. 2010, 163, 327-335. [CrossRef] [PubMed] 
15. Horton, R.K. An index number system for rating water quality. J. Water Poll. Cont. Fed. 1965, 37, $300-305$.

16. Miller, W.W.; Joung, H.M.; Mahannah, C.N.; Garrett, J.R. Identification of water quality differences in Nevada through index application. J. Environ. Qual. 1986, 15, 265-272. [CrossRef]

17. Bordalo, A.A.; Nilsumranchit, W.; Chalermwat, K. Water quality and uses of the Bangpakonk River (Eastern Thailand). Water Res. 2001, 35, 3635-3642. [CrossRef]

18. Yidana, S.M.; Yidana, A. Assessing water quality index and multivariate analysis. Environ. Earth Sci. 2010, 59, 1461-1473. [CrossRef]

19. Aly, A. Hydrochemical characteristics of Egypt western desert oases groundwater. Arab. J. Geosci. 2015, 8, 51-7564. [CrossRef]

20. Magesh, N.S.; Chandrasekar, N. Evaluation of spatial variations in groundwater quality by WQI and GIS technique: A case study of Virudunagar District, Tamil Nadu, India. Arab. J. Geosci. 2013, 6, 1883-1898. [CrossRef]

21. Magesh, N.S.; Krishnakumar, S.; Chandrasekar, N.; John, P.S. Groundwater quality assessment using WQI and GIS techniques, Dindigul district, Tamil Nadu, India. Arab. J. Geosci. 2013, 6, 4179-4189. [CrossRef]

22. Backman, B.; Bodis, D.; Lahermo, P.; Rapant, S.; Tarvainen, T. Application of a groundwater contamination index in Finland and Slovakia. Environ. Geol. 1998, 36, 55-64. [CrossRef]

23. Ketata-Rokbani, M.; Gueddari, M.; Bouhlila, R. Use of Geographical Information System and Water Quality Index to Assess Groundwater Quality in El Khairat Deep aquifer (Enfidha, Tunisian Sahel). Iran. J. Energy Environ. 2011, 2, 133-144.

24. Khashogii, M.S.; El Maghraby, M.M. Evaluation of groundwater resources for drinking and agricultural purposes, Abar Al Mashi area, south Al Madinah Al Munawarah City, Saudi Arabia. Arab. J. Geosci. 2013, 6, 3929-3942. [CrossRef]

25. El Maghraby, M.M. Hydrogeochemical characterization of groundwater aquifer in Al-Madinah Al-Munawarah City, Saudi Arabia. Arab. J. Geosci. 2015, 8, 4191-4206. [CrossRef]

26. Kingdom of Saudi Arabia. Population and Housing Census 1431 H (2010); Riyadh Ministry of Economics and Planning: Riyadh, Saudi Arabia, 2012.

27. Matiti, S.K. Handbook of Methods in Environmental Studies: Water and Wastewater Analysis; ABD Publishers: Jaipur, India, 2004.

28. Tabatabai, M.A. Methods of Soil Analysis. Part 3. Chemical Methods; Sparks, D.L., Page, A.L., Helmke, P.A., Loeppert, R.H., Eds.; SSSA Book Ser. 5; ASA/SSSA: Madison, WI, USA, 1996; pp. 921-960.

29. APHA. Standard Methods for the Examination of Water and Wastewater, 20th ed.; American Public Health Association: Washington, DC, USA, 1998.

30. Bingham, F.T. Boron, Methods of Soil Analysis. Part 2. Chemical and Microbiological Properties; Agronomy Monograph; SSSA: Madison, WI, USA, 1982; pp. 431-447.

31. Critelli, T.; Vespasiano, G.; Apollaro, C.; Muto, F.; Marini, L.; De Rosa, R. Hydrogeochemical study of an ophiolitic aquifer: A case study of Lago (Southern Italy, Calabria). Environ. Earth Sci. 2015, 74, 533-543. [CrossRef]

32. Edberg, S.C.; Allen, M.J.; Smith, D.B. Defined substrate technology method for rapid and specific simultaneous enumeration of total coliforms and Escherichia coli from water: Collaborative study. J. Assoc. Off. Anal. Chem. 1991, 74, 526-529.

33. Fricker, E.J.; Illingworth, K.S.; Fricker, C.R. Use of two formulations of colilert and quantitray( $\left.{ }^{\mathrm{TM}}\right)$ for assessment of the bacteriological quality of water. Water Res. 1997, 31, 2495-2499. [CrossRef]

34. Eckner, K.F. Comparison of membrane filtration and multiple-tube fermentation by the Colilert and Enterolert methods for detection of waterborne coliform bacteria, Escherchia coli, and enterococci used in drinking and bating water quality monitoring in Southern Sweden. Appl. Environ. Microbiol. 1998, 64, 3079-3083. [CrossRef]

35. Maheux, A.F.; Huppé, V.; Boissinot, M.; Picard, F.J.; Bissonnette, L.; Bernier, J.L.; Bergeron, M.G. Analytical limits of four beta-glucuronidase and beta-galactosidase-based commercial culture methods used to detect Escherichia coli and total coliforms. J. Microbiol. Methods 2008, 75, 506-514. [CrossRef]

36. Aly, A.A.; Al-Omran, A.M.; Alharby, M.M. The water quality index and hydrochemical characterization of groundwater resources in Hafar Albatin, Saudi Arabia. Arab. J. Geosci. 2015, 8, 4177-4190. [CrossRef]

37. Ramakrishnalah, C.R.; Sadashivalah, C.; Ranganna, G. Assessment of water quality index for the groundwater in Tumkur Taluk, Karnataka state, India. E-J. Chemistry. 2009, 6, 523-530. [CrossRef] 
38. WHO. Guidelines for Drinking-Water Quality, 4th ed.; World Health Organization: Geneva, Switzerland, 2011.

39. Piper, A.M. A graphic procedure in the geochemical interpretation of water analysis. Trans. Am. Geophys. Union 1944, 25, 914-928. [CrossRef]

40. Schoeller, H. Géochimie des Eaux Souterraines. Aplication aux Eaux des Gisements de Pétrole; Inst. Français duPétrole: Paris, France, 1955.

41. Parkhurst, D.L.; Appelo, C.A.J. User's guide to PHREEQC (version 2)-A computer program for speciation, batch-reaction, one-dimensional transport, and inverse geochemical calculations. Geol. Surv. Water-Res. Investig. Rep. 1999, 99, 312.

42. Alexakis, D. Assessment of water quality in the Messolonghi-Etoliko and Neochorio region (West Greece) using hydrochemical and statistical analysis methods. Environ. Monit. Assess. 2011, 182, 397-413. [CrossRef]

43. Al-Makishah, N.H. Microbial Screening of Groundwater and Surface Water in Agricultural Region Surrounding Al-Madina Al-Monawara. J. King Abdulaziz Univ. Meteorol. Environ. Arid Land Agric. Sci. 2018, 27, 125-137. [CrossRef]

44. WHO. Calcium and Magnesium in Drinking-Water Public Health Significance; World Health Organization: Geneva, Switzerland, 2009.

45. Deshpande, S.M.; Aher, K.R. Evaluation of Groundwater Quality and its Suitability for Drinking and Agriculture use in Parts of Vaijapur, District Aurangabad, MS, India. Res. J. Chem. Sci. 2012, 2, 25-31.

46. Ayers, R.S.; Westcot, D.W. Water Quality for Agriculture; Irrigation and Drainage Paper 29 (rev.1); FAO: Rome, Italy, 1985.

47. Nagaraju, A.; Sunil Kumar, K.; Thejaswi, A. Assessment of groundwater quality for irrigation: A case study from Bandalamottu lead mining area, Guntur District, Andhra Pradesh, South India. Appl. Water Sci. 2014, 4, 385-396. [CrossRef]

48. Todd, D.K.; Mays, L.W. Groundwater Hydrology, 3rd ed.; Wiley: Hoboken, NJ, USA, 2005; p. 656.

49. Richards, L.A. (Ed.) Diagnosis and Improvement of Saline and Alkali Soils; USDA Hand Book. No. 60; US Govt. Press: Washington, DC, USA, 1954; p. 160.

50. Kelly, W.P. In Proceedings of the A.S.C.F. 1940, p. 607. Available online: https://www.cabdirect.org/cabdirect/ abstract/19411900188 (accessed on 15 June 2019).

51. Eaton, F.M. Significance of carbonates in irrigation waters. Soil Sci. 1950, 69, 123-133. [CrossRef]

52. Szabolcs, I.; Darab, C. The influence of irrigation water of high sodium carbonate content of soils. Proc. Int. Congr. Trans. 1964, 2, 803-812.

53. Tiwari, A.K.; Singh, A.K. Hydrogeochemical investigation and groundwater quality assessment of Pratapgarh district, Uttar Pradesh. J. Geol. Soc. India 2014, 83, 329-343. [CrossRef]

54. Nasher, G.; Al-Sayyaghi, A.; Al-Matary, A. Identification and evaluation of the hydrogeochemical processes of the lower part of Wadi Siham catchment area, Tihama plain, Yemen. Arab. J. Geosci. 2013, 6, 2131-2146. [CrossRef]

55. Apollaro, C.; Fuoco, I.; Brozzo, G.; De Rosa, R. Release and fate of Cr (VI) in the ophiolitic aquifers of Italy: The role of $\mathrm{Fe}$ (III) as a potential oxidant of $\mathrm{Cr}$ (III) supported by reaction path modelling. Sci. Total Environ. 2019, 660, 1459-1471. [CrossRef]

56. Vespasiano, G.; Apollaro, C.; De Rosa, R.; Muto, F.; Larosa, S.; Fiebig, J.; Mulch, A.; Marini, L. The Small Spring Method (SSM) for the definition of stable isotope-elevation relationships in Northern Calabria (Southern Italy). Appl. Geochem. 2015, 63, 333-346. [CrossRef]

57. Aly, A.A.; Abbas, A.A.; Benaabidate, L. Hydrochemistry and Quality of Groundwater Resources in Egypt: Case Study of the Egyptian Southern Oases. In Water Security in the Mediterranean Region; Springer: Dordrecht, The Netherlands, 2011; pp. 239-254.

58. Al-Barakah, F.N.; Gassas, A.M.; Aly, A.A. Water Quality Assessment and Hydrochemical Characterization of Zamzam Groundwater, Saudi Arabia. Appl. Water Sci. 2017, 7, 3985-3996. [CrossRef]

(C) 2020 by the authors. Licensee MDPI, Basel, Switzerland. This article is an open access article distributed under the terms and conditions of the Creative Commons Attribution (CC BY) license (http://creativecommons.org/licenses/by/4.0/). 